\title{
IMPLEMENTASI DARI PERKAWINAN YANG TIDAK DICATATKAN TERHADAP PERLINDUNGAN HUKUM ANAK DITINJAU DARI UUNDANG-UNDANG NOMOR 1 TAHUN 1974 DAN UNDANG-UNDANG NOMOR 23 TAHUN 2002 PELAKSANAANYA DI KECAMATAN TANAH KAMPUNG KOTA SUNGAI PENUH
}

\author{
Pidayan Sasnifa \\ Fakultas Syari'ab UIN STS Jambi \\ email: pidayansasnifa@gmail.com
}

\begin{abstract}
The legal consequence of marriage which is not recorded is the status of the child born from the marriage will be unclear because the marriage of his parents is only religiously valid. Although the child is a legitimate child, but does not have outentic evidence that can confirm that the child is a legitimate child of the two masters. The position of a child born of a marriage that is not recorded only has a civil relationship with his mother. Besides that, children born from unregistered marriages will have difficulty obtaining a birth certificate, with no birth certificate for children, the state has obstacles in protecting children, because there is no legal record of the child's birth status along with the data of the two parents who cause the birth of the child. Legal remedies that can be done so that a child born of an unregistered marriage, obtaining a position like a legitimate child, is to submit an application for a determination from the local religious court, or local district court, which is adjusted to the respective child registration office. While efforts can be made if the marriage is only done according to religion, and not recorded in the office of civil records, the child born from the marriage can only be recognized by means of child validation, so that the child becomes a legitimate child. Validation of the child can only be done if the parents record their marriage at the civil registry office first. The research carried out was to describe or describe the legal protection of children from marriage which was not recorded in accordance with Law No. 1 of 1974 and Law Number 23 of 2002 concerning Child Protection. The approach used is a qualitative approach, can be interpreted as research that produces descriptive data about verbal or written words, or observable behavior of the problem under study.
\end{abstract}

Keyword: Legal protection, illegitimate child 


\section{PENDAHULUAN}

Dalam lingkungan keluarga bahagia seorang anak memiliki peranan yang sangat penting karena tujuan perkawinan selain membangun mahligai rumah tangga yang bahagia dan sejahtera juga untuk mempersatukan keluarga dan meneruskan keturunan. ${ }^{1}$

Bangsa Indonesia telah lama mempunyai keinginan untuk memiliki peraturan tentang perkawinan yang bersifat nasional atau unifikasi hukum, berlaku untuk seluruh golongan masyarakat dan untuk seluruh wilayah negara Indonesia. Berdasarkan Pasal 1 Undang-undang Nomor 1 Tahun 1974 Tentang Perkawinan menyatakan bahwa perkawinan adalah ikatan lahir bathin antara seorang pria dengan seorang wanita sebagai suami isteri dengan tujuan membentuk keluarga (rumah tangga) yang bahagia dan kekal berdasarkan Ketuhanan Yang Maha Esa. ${ }^{2}$

Menurut Ahmad Rofiq dalam bukunya "Hukum Islam di Indonesia" menjelaskan bahwa ada dua syarat perkawinan yang harus dipenuhi yakni : syarat materiil dan administratif. ${ }^{3}$ Di dalam Undang-undang perkawinan diatur mengenai syarat sah perkawinan Pasal 2 ayat (1) dan (2).

Perkawinan yang telah dilangsungkan menurut hukum agama dan kepercayaan masingmasing harus dicatat oleh petugas pencatat dengan maksud agar terjadi tertib administrasi pemerintahan dan kependudukan. Terciptanya tertib administrasi kependudukan berarti menghindarkan kekacauan administrasi yang berhubungan dengan kepastian kedudukan hukum seseorang. ${ }^{4}$

Kedudukan anak yang dilahirkan dari suatu perkawinan yang tidak dicatatkan hanya memiliki hubungan perdata dengan ibunya sementara dengan ayahnya tidak memiliki hubungan hukum kecuali jika ada pengakuan dari ayah biologisnya. Maka jika terjadi perceraian, suami tidak lagi mempunyai kewajiban memberikan nafkah baik lahir maupun bathin, isteri akan mengalami kesulitan untuk menggugat suaminya. Hal ini disebabkan tidak adanya bukti bahwa mereka telah melangsungkan perkawinan.

\footnotetext{
1 Soetojo Prawihamidjojo, Plurlisme dalam perundang-undangan Perkawinan di Indonesia, (Jakarta Airlangg University Press,1986), hal. 28-29.

2 Tim Redaksi Nuansa Auliia, Kompilasi Hukum Islam (Hukum Perkawinan, Kewewarisan dan Perwakafan), Bandung: CV. Nuanasa Aulia, 2008) hal. 80.

${ }^{3}$ Ahmad Rofiq, Hukum Islam di Indonesia, (Jakarta: PT. Grafindo Persada, 2003), hal. 70 31.

${ }^{4}$ Witanto, Hukum Keluarga Hak dan Kedudukan Anak Luar Kawin, (Jakarta, Prestasi Pustaka, 2012), hal
} 
Hak dan kewajiban anak tersebut selain diatur dalam hukum nasional juga dalam hukum Internasional. Deklarasi Majelis Umum Perserikatan Bangsa-Bangsa tanggal 20 November 1989, antara lain menyatakan bahwa anak-anak mempunyai hak untuk memperoleh perlindungan khusus, kesempatan dan hak yang memungkinkan mereka berkembang secara sehat dan wajar dalam keadaan bebas dan sesuai dengan martabat kemanusiaan. Konvensi tentang hak-hak anak telah diratifikasi dengan Keputusan Presiden Nomor 36 Tahun 1990, sehingga Indonesia telah terikat melaksanakan Konvensi tersebut. ${ }^{5}$

Kendatipun selama ini masalah Perkawinan dan segala sesuatu yang berkaitan dengannya termasuk di dalamnya masalah perlindungan hukum telah diatur dalam bentuk peraturan perundang-undangan namun kenyataan sampai sekarang masih tetap saja belum dapat dilaksanakan secara optimal dan sesuai degan harapan dan tujuan dibuatkannya peraturan perundang-undangan tersebut. Ada beberapa fenomena yang menunjukkan bahwa undang-undang ini masih belum cukup efektif untuk mencegah praktek perkawinan di bawah tangan, kawin paksa, poligami liar dan lain -lainnya, kasus-kasus seperti inipun terjadi di Kecamatan Tanah Kampung Kota Sungai Penuh, hal ini menandai masih terjadinya pelaksanaan perkawinan yang tidak tercatat. Kesemuanya itu merupakan kendala dalam mewujudkan cita-cita pemberlakuan undang-undang perkawinan dan Undang-undang perlindungan anak sebagaimana telah disebutkan sebelumnya. Berdasarkan dari latar belakang tersebut diatas, maka peneliti merasa tetarik untuk melakukan penelitian dan analisis penerapan pelaksanaan perlindungan hukum terhadap anak dari hasil perkawinan yang tidak dicatatkan dengan menggunakan Undang-undang Nomor 1 tahun 1974 tentang perkawinan dan Undang-undang Nomor 23 tahun 2002 tentang perlindungan anak sebagai bahan acuan dalam menyelesaikan masalah perlindungan hukum terhadap anak dari perkawinan tidak dicatatkan di Kecamatan Tanah Kampung Kota Sungai Penuh.

\section{PEMBAHASAN}

\section{Faktor Penyebab Perkawinan Tidak Dicatatkan di Kecamatan Tanah Kampung}

Meskipun Undang-undang Perkawinan dengan tegas telah menyatakan bahwa perkawinan sah apabila dicatatkan sebagaimana yang terdapat dalam Pasal 2 ayat (2), namun dalam prakteknya masih banyak perkawinan yang tidak dicatatkan. Adapun alasan-alasan suatu perkawinan tidak dicatatkan di Kecamatan Tanah Kampung yaitu karena berbagai

5 Soenaryati Hartono, Politik. Hukum Menuju Satu Sistem Hukum Nasional, (Jakarta: Penerbit Alumni, 1991), hal. 154. 
alasan, sebagaimana yang diungkapkan oleh Bapak M.T, Kepala Pengadilan Agama Kota Sungai Penuh : 1. Perkawinan yang tidak dicatatkan, terutama perkawinan yang dilaksanakan sebelum tahun 1975. Saat diberlakukannya Undang-undang tentang Perkawinan, yaitu Undang-undang Nomor 1 tahun 1974, beserta peraturan pelaksanaannya yaitu Peraturan Pemerintah Nomor 9 tahun 1975, tidak dapat dipungkiri setelah diberlakukannya peraturan perundang-undangan tersebut pun, masih banyak perkawinan yang tidak dicatatkan, karena berbagai alasan diatas. 2. Perkawinan Syiri'. Perkawinan yang hanya dilangsungkan secara agama dan sudah memenuhi syarat sahnya suatu perkawinan tetapi tidak didaftarkan disebut juga perkawinan syiri'. 3. Perkawinan tersebut tidak ingin diketahui umum. Penyebabnya biasanya adalah faktor sosial dan pengaruh budaya, misalnya saja, pernikahan terhadap anak yang masih belum dewasa dengan restu orang tua karena takut anak-anak tersebut melakukan zina, perkawinan anak-anak karena hamil di luar nikah atau perkawinan yang dilakukan diamdiam 4. Masalah biaya, biaya menjadi salah satu penyebab terjadinya perkawinan tidak dicatakan, mengingat masih tingginya biaya yang dikenakan terhadap perkawinan yang dilangsungkan. Hal tersebut di atas menjadi alasan bagi masyarakat untuk tidak mendaftarkan perkawinannya, sehingga perkawinan yang telah dilangsungkan tersebut tidak diakui secara hukum. ${ }^{6}$. 5. Perkawinan Poligami. Perkawinan yang Tidak Memenuhi Syarat Undang-undang Perkawinan memperbolehkan perkawinan poligami, namun dengan pembatasan tertentu..... ${ }^{7}$ Disamping itu selain Faktor-faktor diatas disadari terdapat banyak kendala yang dihadapi pemerintah dan badan kependudukandan kantor catatan sipil (BKKCS), untuk menyadarkan penduduk agar mau mencatatkan perkawinan. Salah satu kendala yang utama adalah ketidak tahuan masyarakat akan pentingnya fungsi pencatatan peristiwa-peristiwa penting dalam kehidupan manusia itu dalam hal ini terutama pencatatan perkawinan. ${ }^{8}$ Selain ketidak tahuan masyarakat akan kegunaan dari pencatatan peristiwa penting dalam hidup manusia, juga karena biaya pendaftaran yang dirasakan cukup mahal oleh masyarakat. Disamping itu sangat banyak pula perkawinan yang tidak dicatatkan, terutama perkawinan yang dilaksanakan sebelum tahun 1975. ${ }^{9}$ Saat diberlakukannya Undang-undang tentang Perkawinan, yaitu Undang- undang Nomor 1 tahun 1974, beserta peraturan pelaksanaannya yaitu Peraturan Pemerintah Nomor 9 tahun 1975, tidak dapat dipungkiri setelah diberlakukannya peraturan perundang-undangan tersebutpun, masih banyak perkawinan yang tidak dicatatkan, karena berbagai alasan diatas.

${ }^{8}$ Wawancara dengan Bapak berinisial HF, Kepala Dinas Kependudukan dan Catatan Sipl Kota Sungai Penuh, pada hari Kamis, tanggal 20 Agustus 2015

${ }^{9}$ Ibid. 
Selain itu dicatatkan perkawinan di dua instansi, yaitu Kantor Urusan Agama dan Kantor Catatan Sipil, juga menimbulkan berbagai masalah. Ada banyak hal yang menyebabkan seorang tidak bisa mencatatkan perkawinannya, sehingga anak-anak yang dilahirkan dari perkawinan yang tidak dicatatkan anak tersebut tidak memiliki akta kelahiran karena dasar untuk dicatatkan kelahiran bagi seorang anak adalah tercatatnya perkawinan orang tuanya. Disamping alasan tersebut banyak juga anak yang dilahirkan dari perkawinan yang tercatat tapi tidak memiliki akta kelahiran yang sah, hal ini disebabkan para orang tua tidak memahami arti penting akta kelahiran, karena pembuatan akta dinilai terlalu sulit dan mahal.

Selain karena kurangnya pencatatan kelahiran yang komprehensif, birokrasi berbelitbelit dan sistem yang terlalu tersentralisir juga mengakibatkan masyarakat menjadi apatis untuk mencatatkan kelahiran anak mereka.

\section{Akibat Hukum Perkawinan Yang Tidak Dicatatkan Terhadap Anak Menurut Undang-undang Nomor 1 Tahun 1974 dan Undang-Undang No. 23 Tahun 2002}

Undang-undang Perkawinan memberikan status yang jelas dan pasti bagi seorang anak luar kawin. Berdasarkan hasil penelitian bahwa, akibat hukum apabila suatu perkawinan tidak dicatatkan terhadap anak adalah kedudukan anak tersebut menjadi anak tidak sah, anak tersebut hanya memiliki hubungan perdata dengan ibunya. sehingga anak yang dilahirkan dari perkawinan yang tidak dicatatkan akan kesulitan mendapatkan akta kelahiran yang sah.

Hal ini diperjelaskan oleh kepala Dinas Kependudukan dan Catatan Sipil Kota Sungai, mengatakan bahwa, bila seseorang anak tidak mempunyai akta kelahiran, maka negara mempunyai hambatan dalam melindungi anak, karena secara hukum tidak ada catatan tentang status kelahiran anak beserta data-data kedua orang tua yang menyebabkan kelahiran anak tersebut. Akta kelahiran merupakan dasar bagi seorang anak untuk mendapatkan hak-haknya baik dari orang tuanya sendiri maupun dari negara. ${ }^{10}$ Pada dasarnya bagi perkawinan yang tidak dicatatkan maka perkawinan tersebut menjadi tidak sah menurut negara, terhadap mereka baik isteri maupun anak-anak yang dilahirkan dari perkawinan tersebut menurut hukum tidak akan mendapat perlindungan hukum yang pasti dan tegas salah satunya adalah dalam hal nafkah hidup dan juga hak waris. Anak tidak akan mendapatkan hak waris dari ayah dan keluarga ayahnya karena anak luar kawin hanya mempunyai hubungan dengan ibu dan keluarga ibunya akibatnya dia hanya punya hak waris dari ibu dan keluarga ibu, yang mempunyai hak waris dari ayahnya hanyalah anak-anak yang dilahirkan dalam perkawinan

10 Wawancara dengan Bapak berinisial HF, Kepala Dinas Kependudukan dan Catatan Sipl Kota Sungai Penuh, pada hari Kamis, tanggal 20 Agustus 2015 
yang sah menurut hukum yang ada. Berdasarkan hasil pengamatan dan penelitian peneliti dilapangan, dimasyarakat masih banyak perkawinan yang tidak dicatatkan, hal ini disebabkan, perkawinan dilakukan secara dibawah tangan, sehingga mengakibat akan berdampak kepada hak waris terutama hak waris anak. Hal tersebut juga dipertegas oleh Kepala Pengadilan Agama Kota Sungai Penuh, mengatakan bahwa ${ }^{11}$ :

"Pada dasarnya perkawinan yang dilakukan dibawah tangan tanpa izin dari pengadilan maka perkawinan tersebut tidak sah, terbadap mereka baik isteri maupun anak-anak yang dilabirkan dalam perkawinan dibawah tangan menurut bukum tidak akan mendapat perlindungan bukum yang pasti dan tegas dalam hal waris dari bapak biologisnya, sedangkan si anak banya berhake mewaris dari ibu dan keluarga ibunya".

Disamping itu perkawinan yang tidak dicatatkan juga akan berakibat terlanggarnya hak anak yang lain. Hal ini sebagaimana dikatakan oleh Bapak DA, Panitera pada Pengadilan Agama Sungai Penuh, Beliau mengatakan bahwa :

"Perkawinan yang tidak dicatatkan akan berakibat terlanggarnya hak-bak anak diantaranya terabaikannya hak anak seperti hak mendapat pemeliharaan yang baik dari orang tuanya pada kenyataannya banyak, pernikahan yang tidak dicatatkan yang terkadang menimbulkan tidak adanya rasa tanggung jawab orang tua terhadap anaknya terutama ayah, anak tidak dapat pendidikan yang baik serta bak lainnya. Karena tanpa pencatatan perkawinan seorang anak tidak akan mempunyai bubungan bukum baik. dengan ayah maupun keluarga ayahnya". ${ }^{12}$

Hal senada juga diungkapkan oleh Kepala Pengadilan Agama Kota sungai Penuh. Menurut beliau sebaiknya perkawinan yang telah dilaksanakan menurut agama masing-masing, hendaknya dicatatkan sehingga diakui oleh hukum negara dan mendapatkan perlindungan hukum yang tegas tidak hanya dalam hukum waris maupun hak-hak lainnya seperti hak anak untuk mendapatkan pemeliharaan yang baik dari orang tuanya, hak mendapatkan nafkah hidup, hak mendapatkan pendidikan dan yang paling penting hak untuk mendapatkan identitas berupa akta kelahiran. ${ }^{13}$ Peristiwa penting dalam kehidupan seseorang seperti perkawinan perlu dicatatkan, sehingga dengan adanya pencatatan akan ada hubungan hukum antara suami-isteri serta anak-anak yang dilahirkan dari perkawinan tersebut sehingga mereka mendapatkan status yang jelas dan diakui keberadaanya oleh negara. Dan dapat memperoleh hak-haknya sebagaimana mestinya.

11 Wawancara dengan Bapak berinisial MT, Kepala Pengadilan Agama Kota Sungai Penuh, pada hari Senin, tanggal 24 Agustus 2015

12 Wawancara dengan Bapak berinisial DA, Panitera Pengadilan Agama Kota Sungai Penuh, pada hari Senin, tanggal 24 Agustus 2015

${ }^{13}$ Wawancara dengan Bapak berinisial, M.T, Kepala Pengadilan Agama Kota Sungai Penuh, pada hari Senin, tanggal 24 Agustus 2015 


\section{Upaya Hukum yang Dapat Dilakukan Terhadap Anak yang Dilahirkan Dari Perkawinan yang Tidak Dicatatkan}

Pencatatan perkawinan bertujuan untuk menjadikan peristiwa perkawinan itu menjadi jelas, baik bagi yang bersangkutan maupun bagi orang lain dan masyarakat, karena dapat dibaca dalam suatu surat yang bersifat resmi dan termuat pula dalam suatu daftar yang khusus disediakan untuk itu, sehingga sewaktu-waktu dapat dipergunakan dimana perlu, terutama sebagai suatu alat bukti tertulis yang otentik.

Tidak adanya pencatatan tentang segala hal yang berhubungan dengan keperdataan seseorang mengakibatkan orang yang tidak dicatatkan tersebut tidak mendapatkan status yang jelas dari negara. Keadaan demikian akan menyulitkan orang tersebut jika dikemudian hari dibutuhkan bukti outentik untuk mendapatkan hak-hak keperdataannya. Bukti-bukti otentik yang dapat digunakan untuk mendukung kepastian, tentang kedudukan seseorang itu ialah adanya akta yang dikeluarkan oleh satu lembaga, dimana lembaga inilah yang berwenang untuk mengeluarkan akta-akta mengenai kedudukan seseorang. Apabila peristiwa yang penting dalam hidup manusia termaksud tidak dicatatkan dalam register catatan sipil tersebut, maka akan timbul ketidak pastian hukum terutama tentang status keperdataan seseorang. Oleh karena itu didasarkan Undang-undang Perkawinan, perkawinan sah apabila dilakukan berdasarkan Pasal 2 ayat (1) dan ayat (2) dimana dalam ayat (2) disebutkan bahwa: tiap-tiap perkawinan dicatat menurut peraturan perundang-undangan yang berlaku.

Berdasarkan Pasal 2 (2) Undang-undang Perkawinan tiap perkawinan dicatat menurut peraturan yang berlaku. Kiranya dapatlah dikatakan bahwa pencatatan perkawinan itu bertujuan untuk menjadikan peristiwa perkawinan itu menjadi jelas, baik bagi yang bersangkutan maupun bagi orang lain dan masyarakat, karena dapat dibaca dalam satu surat yang bersifat resmi dan termuat pula dalam suatu daftar yang khusus disediakan untuk itu, sehingga sewaktu-waktu dapat dipergunakan dimana perlu terutama sebagai alat bukti tertulis yang otentik. Dengan adanya surat bukti itu dapatlah dibenarkan atau dicegah suatu perbuatan yang lain. Hal ini dilakukan dengan maksud agar terjadi tertib administrasi pemerintahan dan agar tercapai kepastian hukum, pencatatan perkawinan itu sangat diperlukan karena dalam negara mengatur segala hal-hal yang bersangkut paut dengan penduduk harus dicatat, sebagai kelahiran, perkawinan, kematian dan sebagainya. Lagi pula perkawinan berkaitan erat dengan waris-mawaris sehinggga perkawinan perlu dicatat menjaga jangan sampai ada kekacauan. Walaupun Undang-undang Perkawinan dan Peraturan Pelaksanaannya Nomor 9 Tahun 1975 telah menyatakan dengan tegas bahwa perkawinan yang telah dilangsungkan secara agama harus dicatat tetapi dalam kenyataannya masih banyak masyarakat yang melakukan perkawinan 
tanpa dilakukan pencatatan. Seharusnya setiap perkawinan yang telah dilangsungkan secara agama harus dicatatkan karena dari pencatatan perkawinan akan diterbitkan akta perkawinan yang akan menjadi alat bukti telah terjadinya perkawinan. ${ }^{14}$

\section{Pelaksanaan Perlindungan Hukum Terhadap Anak yang Dilahirkan dari Perkawinan Yang Tidak Dicatatkan Menurut Undang-undang Nomor 1 Tahun 1974 Tentang Perkawinan dan Undang-undang Nomor 23 tahun 2002 Tentang Perlindungan Anak di Kecamatan Tanah Kampug.}

Negara mempunyai kepentingan terhadap kelangsungan hidup anak, sebagai generasi penerus yang pada gilirannya akan meneruskan kelangsungan negara. Oleh karena itu perlindungan terhadap anak, selain sebagai hak setiap subjek hukum untuk mendapatkannya, ada pula kepentingan negara untuk melaksanakannya. Perlindungan hukum bagi anak, merupakan salah satu sisi perlindungan anak. Hukum perlindungan anak merupakan jaminan pelaksanaan hak-hak anak dibidang hukum. Perlindungan anak secara yuridis merupakan upaya yang ditujukan untuk mencegah agar anak tidak mengalami perlakuan salah (child abused) baik langsung maupun tidak langsung, menjamin kelangsungan hidup dan tumbuh kembang anak dengan wajar, baik fisik, mental dan sosial. Pasal 3 Undang-undang Nomor 23 Tahun 2002 Tentang Perlindungan Anak menetapkan : "Perlindungan anak bertujuan untuk menjamin terpenuhinya hak-hak anak agar dapat hidup, tumbuh, berkembang, dan berpartisipasi secara optimal sesuai dengan harkat dan martabat kemanusiaan serta mendapat perlindungan dari kekerasan dan diskriminasi, demi terwujudnya anak Indonesia yang berkualitas, berakhlak mulia dan sejahtera." Kepentingan negara terhadap kesejahteraan dan kelangsungan generasi penerus, melahirkan kewajiban negara untuk memberikan perlindungan terhadap anak, salah satunya adalah perlindungan hukum anak. Pentingnya perlindungan hukum anak dengan dilakukannya pencatatan kelahiran, selain untuk kepentingan administrasi negara, juga untuk kepentingan anak itu sendiri apabila anak telah menjadi dewasa dan harus memenuhi kepentingannya sendiri dalam melakukan bermacam-macam aktivitas yang antara lain melakukan pekerjaan.

Kewajiban negara dalam memberi perlindungan hukum melalui pencatatan kelahiran, adalah dengan antara lain memberikan kemudahan pendaftaran kelahiran, dalam arti dibuat petunjuk pelaksanaan yang mudah dimengerti dan tidak menyulitkan dalam pengurusan. Kemudian Kantor Kependudukan dan Catatan Sipil perlu koordinasi dengan desa dan rumah

14 Wawancara dengan Bapak berinisial PL, Kepala Seksi Kelahiran, Kematian Adopsi Anak Ganti Nama, Dinas Kependudukan dan Catatan Sipil Pemerintah Kota Sungai Penuh, Pada Hari Kamis, Tanggal 20 Agustus 2015 
sakit, dalam hal ada hal-hal yang meragukan sehingga tidak terjadi kesalahan yang nantinya berakibat fatal. Sebagaimana diungkapkan oleh Bapak berinisial HF, Kepala Dinas Kependudukan dan Catatan Sipl Kota Sungai, Menurut beliau :

"Pendaftaran dimanapun selalu membutubkan biaya, namun untuk, bal yang satu ini, pencatatan kelabiran, yang mempunyai fungsi yang demikian besarnya, perlu diberi keringanan yang dapat dijangkau oleh masyarakat yang paling bawah babkan kalau bisa diberikan secara gratis. Pemberian akta kelahiran secara gratis telah dicanangkan oleh pemerintah pada akbir Tabun 2006 namun pada praktiknya tetap saja ada biaya yang barus dikeluarkan untuk. mendapatkan akta kelabiran ini" ${ }^{15}$

Pada pelaksanaanya perkawinan yang tidak dicatatkan mengakibatkan tidak adanya Akta Perkawinan. Perkawinan tersebut tidak dapat dibuktikan karena tidak adanya Akta Perkawinan, sehingga mengakibatkan anak yang lahir dari perkawinan tersebut berkedudukan sebagai anak luar kawin karena dalam Akta Kelahirannya hanya tercantum nama ibunya saja. Upaya hukum yang dapat dilakukan agar seorang anak yang lahir dari perkawinan yang tidak dicatatkan memperoleh kedudukan sebagai anak sah bagi pasangan yang beragama Islam dalam praktik sering dilakukan yaitu dengan mengikuti acuan dalam Pasal 7 Kompilasi Hukum Islam, berbunyi : (1) Perkawinan hanya dapat dibuktikan dengan Akta Nikah yang dibuat oleh Pegawai Pencatat Nikah. (2) Dalam hal perkawinan tidak dapat dibuktikan dengan Akta Nikah dapat diajukan Itsbat Nikahnya ke Pengadilan Agama (3) Itsbat Nikah yang dapat diajuakan ke Pengadilan Agama.

Akta perkawinan tersebut sebagai salah satu syarat untuk dapat dikeluarkannya akta kelahiran yang didalamnya menyebutkan bahwa anak yang lahir tersebut merupakan anak sah dari ayah dan ibu yang disebutkan pada akta kelahiran tersebut berdasarkan Akta Perkawinan kedua orang tuanya.

Pembuktian anak sah berdasarkan keturunan dapat dibuktikan dengan akta kelahiran. Surat atau akta lahir memang membuktikan bahwa seorang anak yang namanya disebutkan di sana adalah anak dari orang yang disebutkan dalam akta kelahiran yang bersangkutan paling tidak dari perempuan yang melahirkan anak itu, yang namanya disebutkan di sana. Akta kelahiran juga menyebutkan bahwa anak yang bersangkutan lahir pada hari dan tanggal tertentu. Saat kelahiran dihubungkan dengan status perkawinan dari perempuan yang melahirkan anak itu, menentukan hubungan anak itu dengan suami dari ibu anak itu. Pasal 55 ayat (1) dan (2) Undang-undang Perkawinan menyatakan bahwa : (1) Asal usul seorang anak hanya dapat dibuktikan dengan akta kelahiran yang otentik, yang dikeluarkan oleh pejabat yang

\footnotetext{
15 Wawancara dengan Bapak berinisial HF, Kepala Dinas Kependudukan dan Catatan Sipl Kota Sungai Penuh, pada hari Kamis, tanggal 20 Agustus 2015
} 
berwenang. (2) Disebutkan bila akta kelahiran tersebut dalam ayat (1) Pasal ini tidak ada, maka pengadilan dapat mengeluarkan penetapan tentang asal usul seorang anak setelah diadakan pemeriksaan yang teliti berdasarkan bukti-bukti yang memenuhi syarat.

Sementara itu untuk Perkawinan bagi pasangan selain Islam yang pencatatannya dilakukan di kantor catatan sipil upaya yang dapat dilakukan apabila perkawinan yang hanya dilakukan menurut agama saja dan tidak dicatatkan di kantor sipil anak yang lahir dari perkawinan tersebut hanya bisa diakui dengan cara pengesahan anak sehingga anak tersebut menjadi anak sah. Pengesahan anak sehingga anak tersebut menjadi anak yang sah hanya dapat dilakukan apabila orang tuanya mencatatkan perkawinannya di Kantor Catatan Sipil terlebih dahulu sedangkan sebelum perkawinan dicatatkan maka anak tersebut hanya bisa mendapatkan akta kelahiran dengan mencantumkan nama ibu saja atau disebut juga sebagai anak luar kawin. ${ }^{16}$ Setelah dilakukan upaya hukum tersebut dengan diterbitkan akta nikah kemudian Akta kelahiran anak, barulah seorang anak bisa mendapat perlindungan hukum dan kedudukannya menjadi anak sah, sehingga memperoleh hak-haknya sebagai subyek hukum yaitu mempunyai hak-hak sipil dan kemerdekaan, maksudnya adalah hak-hak seorang yang diperoleh atau merupakan kewajiban negara untuk mewujudkannya. Dalam wawancara dengan peneliti, Bapak berinisial PL, Kepala Seksi Kelahiran, Kematian, Adopsi Anak, Ganti Nama, Dinas Kependudukan dan Catatan Sipil Pemerintah Kota Sungai Penuhi menygatakan bahwa: $:^{17}$

'Dalam praktik pihak. Kantor Catatan Sipil memerlukan keterangan pembuktian pernikahan, sebagai salah satu syarat untuk dapat dibuatkan Akta Kelahiran. Pencatatan sipil terhadap setiap peristiwa bukum yang terjadi akan berpengaruh dalam masalah perkawinan, pewarisan, kematian dan status seorang anak".

Dengan demikian, setelah adanya pengesahan akta kelahiran, maka anak akan memperoleh jaminan perlindungan hukum yang formil. Sebagai sesuatu lembaga hukum, Pemerintah harus mengatur agar kepentingan- kepentingan anak tersebut terjamin. Mengenai hak anak ini diatur dalam Undang-undang Perkawinan yang menyebutkan mengenai hak anak sebagai berikut :

a. Anak berhak dipelihara dan dididik oleh orang tua mereka dengan sebaik- baiknya. (Pasal 45 ayat (1)

\footnotetext{
16 Wawancara dengan Bapak berinisial HF, Kepala Dinas Kependudukan dan Catatan Sipl Kota Sungai Penuh, pada hari Kamis, tanggal 20 Agustus 2015

17 Wawancara dengan Bapak berinisial PL, Kepala Seksi Kelahiran, Kematian, Adopsi Anak, Ganti Nama, Dinas Kependudukan dan Catatan Sipil Pemerintah Kota Sungai Penuh, pada hari Kamis, tanggal 20 Agustus 2015
} 
b. Anak berhak berada di bawah kekuasaan orang tuanya selama mereka tidak dicabut dari kekuasaannya.(Pasal 47 ayat (1)

c. Anak berhak diwakili orang tua mengenai segala perbuatan hukum di dalam dan di luar pengadilan (Pasal 47 Ayat (1).

d. Anak berhak mendapat biaya pemeliharaan dari orang tua meskipun dalam hal orang tua dicabut kekuasaanya.(Pasal 49 ayat (2) Lebih khusus diatur dalam Undang-undang Nomor 23 Tahun 2002 Tentang Perlindungan Anak, yang menyebutkan bahwa setiap anak berhak untuk. Hidup, tumbuh, berkembang dan berpartisipasi secara wajar sesuai dengan harkat dan martabat kemanusiaan, serta mendapat perlindungandari kekerasan dan diskriminasi.

Hak ini sesuai dengan ketentuan pasal 28 B ayat (2) Undang-undang Dasar 1945 dan prinsip-prinsip pokok yang tercantum dalam Konversi hak anak berbunyi :

(1) Setiap anak berhak atas suatu nama sebagai identitas diri dan status kewarganegaraan. Anak didaftarkan segera setelah kelahiran dan sejak lahir berhak atas sebuah nama, berhak memperoleh kewarganegaraan dan sejauh yang memungkinkan dipelihara oleh orang tuanya. (Pasal 5)

(2) Setiap anak berhak untuk mengetahui orang tuanya, dibesarkan dan diasuh orang tuanya sendiri. Hak anak untuk mengetahui siapa orang tuanya dalam arti asal usulnya, dimaksudkan untuk menghindari terputusnya silsilah dan hubungan darah antaraanak dengan orang tua kandungnya, sedangkan hak untuk dibesarkan dan diasuh orang tuanya dimaksudkan agar anak dapat patuh dan menghormati orang tuanya.

(3) Hak untuk memperoleh pelayanan kesehatan dan jaminan sosialsesuai dengan kebutuhan fisik, mental, spiritual dan sosial.

(4) Hak mendapat pendidikan dan pengajaran (Pasal 9) Setiap anak berhak memperoleh pendidikan dan pengajaran dalam rangka pengembangan pribadinya dan tingkat kecerdasannya sesuai dengan minat dan bakatnya.

(5) Berhak mendapat perlindungan. (Pasal 13) Setiap anak selama dalam pengasuhan orang tua, wali, berhak mendapat perlindungan dari perlakuan diskriminasi, eksploitasi, penelantaran, kekerasan, ketidakadilan, perlakuan salah lainnya.

(6) Hak diasuh orang tuanya. (pasal 14) Setiap anak berhak untuk diasuh oleh orang tuanya sendiri kecuali jika ada alas an dan atau aturan hukum yang sah menunjukan bahwa pemisahan itu adalah demi kepentingan terbaik bagi anak dan pertimbangan terakhir. Pemisahan dimaksud tidak menghilangkan hubungan anak dan orang tuanya.

(7) Hak memperoleh perlindungan dari penganiayaan, penyiksaan atau penjatuhan hukuman yang tidak manusiawi Pasal 16 ayat (1) 
Sementara itu merujuk kepada Undang-undang Nomor 23 Tahun 2002 Tentang Perlindungan Anak maka seharusnya mengenai akta kelahiran anak tidak akan ada masalah karena undang-undang ini non diskriminasi artinya tidak dibeda-bedakan apakah anak-anak tersebut dilahirkan dari perkawinan yang dicatatkan. Disamping itu dalam Pasal 5 Undangundang Nomor 23 Tahun 2002 Tentang Perlindungan Anak disebutkan bahwa setiap anak berhak atas suatu nama sebagai identitas diri dan status kewaganegaraan. Identitas tersebut berupa akta kelahiran dan karena identitas tersebut merupakan hak seharusnya tanggung jawab negaralah untuk memberikannya namun kalau dilihat dalam praktiknya akta kelahiran bagi seorang anak sangat sulit diperoleh apalagi kalau dilihat dari data yang telah disebutkan bahwa sekitar 40\% anak Indonesia tidak mempunyai akta kelahiran ini membuktikan bahwa pelaksanaan dari pada Undang-undang Nomor 1 Tahun 1974 dan undang-udang Nomor23 Tahun 2002 di Kecamatan Tanah Kampung belum terlaksana dengan sempurna..

Untuk itu seharusnya pemeritah memberikan perhatian khusus terhadap masalah ini dan dapat mengeluarkan Peraturan Pelaksana dari Undang-undang Nomor 23 Tahun 2002 Tentang Perlindungan Anak yang mengatur lebih lanjut secara jelas dan tegas mengenai hakhak anak terutama hak yang paling mendasar yaitu untuk mendapatkan akta kelahiran sehingga semua anak mendapatkan Akta kelahiran dan diakui sebagai Warga Negara Indonesia dan diberikan hak-haknya yang lain seperti yang telah disebutkan diatas.

Permasalahan yang sangat mendasar mengenai anak yang dilahirkan dari perkawinan yang tidak dicatatkan adalah mengenai terlanggarnya Hak Anak yaitu kesulitan mendapatkan Identitas berupa akta kelahiran, padahal akta kelahiran merupakan hak anak pertama yang seharusnya diberikan oleh negara. Undang-undang Perlindungan Anak menyatakan dengan jelas bahwa setiap anak berhak mendapatkan identitas. Dalam arti Undang-undang ini tidak membeda-bedakan anak yang dilahirkan dari orang tua yang perkawinannya dicatatkan atau dari orang tua yang perkawinannya tidak dicatatkan. Karena dalam Pasal 1 Undang-undang Perlindungan Anak disebutkan bahwa: "Anak adalah seseorang yang belum berusia 18 (delapan belas) tahun, termasuk anak yang masih di dalam kandungan”. Perkawinan yang tidak dicatatkan akan memberikan dampak yang besar terhadap hak-hak anak, terutama hak anak untuk mendapatkan identitas atas kelahiran mereka sebagai bentuk pengakuan dari orang tua maupun dari Negara. Kesulitan mendapatkan identitas mengakibatkan banyak anak yang tidak memiliki akta kelahiran. Berdasarkan data yang dikumpulkan pada saat ini hanya $40 \%$ anakanak Indonesia pada usia 5 tahun yang memiliki akta kelahiran, sisanya tidak mempunyai catatan kelahiran dan tidak mempunyai akta, akibatnya mereka terancam hak-haknya sebagai warga negara. Hal ini disebabkan oleh beberapa faktor, antara lain sulitnya birokrasi dan 
adanya diskriminasi, Prakteknya pada saat orang tua ingin mendaftarkan kelahiran anaknya kecatatan sipil sebagai instansi pemerintah harus memenuhi berbagai persyaratan administrasi antara lain dikenakan biaya, mengenai biaya ini setiap catatan sipil di masing-masing daerah menentukan besarnya biaya berbeda-beda tergantung kebijaksanaan masing-masing daerah karena biaya pencatatan ini dijadikan sumber pemasukan untuk pembiayaan daerah. Biaya pencatatan berkisar antara Rp. 50.000 (Lima Puluh Ribu Rupiah) sampai - Rp 100.000 (Seratus Ribu Rupiah). Kendala utama seorang anak mendapatkan haknya perihal identitas, adalah tidak tercatatnya perkawinan orang tuanya sehingga tidak mencukupi syarat untuk melakukan pendaftaran di Kantor Catatan Sipil. Selain itu biaya yang relatif mahal dan berbedanya besar biaya yang harus dikeluarkan ditiap daerah juga menjadi kendala yang harus diperhatikan oleh pemerintah mengingat kemampuan financial masyarakat pelaku perkawinan yang tidak dicatat ini banyak yang merupakan masyarakat miskin. Mengenai prosedur dan persyaratan yang rumit serta tingkah laku petugas pencatatan yang tidak kondusif juga merupakan penyebab rendahnya keinginan masyarakat untuk mencatatkan sebuah peristiwa kelahiran.

\section{PENUTUP}

Faktor- faktor penyebab terjadinya perkawinan yang tidak dicatatkan dikecamatan Tanah Kampung Kota Sungai Penuh dikarenakan : Terutama perkawinan yang dilaksanakan sebelum tahun 1975, Perkawinan Syiri', Perkawinan yang tidak ingin diketahui umum karena faktor sosial dan pengaruh budaya, Masalah biaya, biaya dan Perkawinan Poligami.

Akibat hukum apabila suatu perkawinan tidak dicatatkan terhadap anak, kedudukan anak tersebut akan menjadi anak tidak sah, anak tersebut hanya memiliki hubungan perdata dengan ibunya, anak tersebut hanya punya hak waris dari ibu dan keluarga ibunya. Disamping itu anak yang dilahirkan dari perkawinan yang tidak dicatatkan akan kesulitan mendapatkan akta kelahiran. Dengan tidak adanya akta kelahiran terhadap anak, berdasarkan hasil wawancara peneliti, maka negara mempunyai hambatan dalam melindungi anak, karena secara hukum tidak ada catatan tentang status kelahiran anak beserta data-data kedua orang tua yang menyebabkan kelahiran anak tersebut jadi akta kelahiran merupakan dasar bagi seorang anak untuk mendapatkan hak - haknya baik dari orang tuanya sendiri, sehingga pemerintah kesulitan untuk membuat akta kelahiran anak tersebut.

Upaya hukum yang dapat dilakukan agar seorang anak yang lahir dari perkawinan yang tidak dicatatkan, untuk memperoleh status menjadi anak sah bagi pasangan yang beragama 
Islam adalah mengajukan permohonan Itsbat Nikah Kepengadilan Agama dengan maksud agar Pengadilan Agama menetapkan pengesahan perkawinan. Sementara itu untuk Perkawinan bagi pasangan selain Islam yang pencatatannya dilakukan di Kantor Catatan Sipil, upaya yang dapat dilakukan apabila perkawinannya hanya dilakukan menurut agama saja dan tidak dicatatkan di kantor sipil, Pengesahan anak hanya dapat dilakukan apabila orang tuanya mencatatkan perkawinannya pada kepaniteraan pengadilan negeri.

Pelaksanaan perlindungan hukum atas hak-hak anak yang lahir dari perkawinan yang tidak dicatatkan menurut Undang-undang No. 1 Tahun 1974 dan Undang-undang No.. 23 tahun 2002 di Kecamatan Tanah Kampung Kota Sungai Penuh belum terlaksana dengan sempurna karena masih terdapat perkawinan yang tidak dicatatkan dan masih ada anak yang belum mempunyai akta kelahiran.

\section{REFERENSI}

Afandi, Ali "Hukum Waris, Hukum Keluarga Dan Hukum Pembuktian”, Jakarta: PT. Rineka Cipta, 1997.

Departemen Sosial, Pedoman Perlindungan Anak, Jakarta : Direktorat Bina KesejahteraanAnak, Keluarga dan Lanjut Usia, 1990

Gatot supramono, Segi-Segi Hukum Hubungan Luar Nikah, Jakarta: Djambatan, 1998

Gosita, Arif, Masalah Perlindungan Anak, Jakarta : Presindo 1990

Hartono, Soenaryati, Politik Hukum Menuju Satu Sistem Hukum Nasional, Jakarta: Penerbit Alumni, 1991

Hazairin, Tinjauan Mengenai Undang-Undang Perkawinan Nomor 1 tabun1974, Jakarta: Tinta Mas, 1975

J Satrio, Hukum Keluarga Tentang Kedudukan Anak Dalam Undang-Undang, Bandung : Citra Aditya Bakti, 2005

J. Meleong, Lexy, Metodologi Penelitian kualitatif, (Jakarta Renika Cipta: 1998),

Krisnawati, Emiliana, Aspek Hukum Perlindungan Anak, Bandung 2005

M. Situmorang ,Victor, Aspek Hukum Akta Catatan Sipil di Indonesia, Jakarta: Sinar Grafika, 1992

Prawihamidjojo, Soetojo, Pluralisme dalam perundang-undangan Perkawinan di Indonesia, Jakarta Airlangga University Press,1986.

Prinst, Darwan, Hukum Anak Indonesia, Bandung: Citra Aditya Bakti, 2003 
IMPLEMENTASI DARI PERKAWINAN YANG TID AK DICATATKAN TERHADAP PERLINDUNG AN HUKUM ANAK DITINJAU DARI UUNDANG-UNDANG NOMOR 1 TAHUN 1974 DAN UND ANG-UNDANG NOMOR 23 TAHUN 2002 PELAKSANAANYA DI KECAMATAN TANAH KAMPUNG KOTA SUNGAI PENUH

Ramulyo, Mohd, Idris, Hukum Perkawinan Islam, Suatu Analisis Dari Undang-Undang No. 1 Tabun 1974 dan Kompilasi Hukum Islam, Jakarta : PT. Bumi Aksara, 2004.

Rofiq, Ahmad. Hukum Islam di Indonesia, Jakarta: Raja Grafindo Persada, 2003.

Saleh, K Wantjik, Hukum Perkawinan Indonesia, Jakarta: Galia Indonesia, 1980

Setiady, “Intisari Hukum Adat Indonesia dalam kajian kepustakaan”, Alfabeta, Bandung, 2008.

Soemiyati, Hukum Perkawinan Islam dan Undang-undang Perkawinan, Yogyakarta: Liberty, 1999

Syarifuddin Amir, Hukum Perkawinan di Indonesia, Jakarta: Kencana, 2008

Thalib, Sayuti. Hukum Kekeluargaan Indonesia, Jakarta: Universitasa Indonesia Press,cetakan ke$\mathrm{v}, 1986$.

Tim Redaksi Nuansa Aulia, Kompilasi Hukum Islam,(Hukum Perkawinan, Kewarisan, dan perwakafan. Bandung: Nuansa Aulia,2008.

Witanto, D.T, Hukum Keluarga Hak dan Kedudukan Anak Luar Kawin, (Paasca Keluarnya Putusan MK Tentang Uji Materiil UU Perkawinan), Jakarta: Prestasi Pustaka, 2012 